\title{
The influence of algal densities on the toxicity of chromium for Ceriodaphnia dubia Richard (Cladocera, Crustacea)
}

\author{
Rodgher, S.* and Espíndola, ELG.* \\ Centro de Recursos Hídricos e Ecologia Aplicada, Escola de Engenharia de São Carlos, \\ Universidade de São Paulo - USP \\ Av. Trabalhador São Carlense, 400, CP 292, CEP 13560-970, São Carlos, SP, Brazil \\ *e-mail: surodgher@uol.com.br, elgaeta@sc.usp.br
}

Received October 3, 2006 - Accepted January 9, 2007 - Distributed May 31, 2008

(With 3 figures)

\begin{abstract}
Food availability may affect metal toxicity for aquatic organisms. In the present study, the influence of high, medium and low densities of the algae Pseudokirchneriella subcapitata $\left(10^{6}, 10^{5}\right.$ and $10^{4}$ cells. $\mathrm{mL}^{-1}$, respectively) on the chronic toxicity of chromium to the cladoceran Ceriodaphnia dubia was investigated. C. dubia was exposed to a range of chromium concentration from 2.71 to $34.04 \mu \mathrm{g} . \mathrm{L}^{-1}$ and fed with algae at various densities. In another experiment, the green alga was exposed to chromium concentrations (94 to $774 \mu \mathrm{g} . \mathrm{L}^{-1}$ ) and supplied as food in different densities to zooplankton. The survival and reproduction of the cladoceran were measured in these toxicity tests. The IC50 for Cr to P. subcapitata and metal accumulated by algal cells were determined. The results of a bifactorial analysis (metal versus algal densities) showed that metal toxicity to zooplankton was dependent on algal densities. Significant toxic effects on the reproduction and survival of $C$. dubia were observed at 8.73, 18.22 and $34.04 \mu \mathrm{g} . \mathrm{L}^{-1} \mathrm{Cr}$ when the test organisms were fed with $10^{6}$ cells. $\mathrm{mL}^{-1}$ of $P$. subcapitata. Although the chlorophyta retain low chromium content, a decrease in the reproduction and survival of $C$. dubia occurred when they were fed with high algal density contaminated with $774 \mu \mathrm{g}$.L $\mathrm{L}^{-1} \mathrm{Cr}$. It was concluded that high algal density have an appreciable influence on chromium toxicity to daphnids.
\end{abstract}

Keywords: metal, chronic toxicity, food, Pseudokirchneriella subcapitata, zooplankton.

\section{Influência de diferentes densidades algais sobre a toxicidade do cromo para Ceriodaphnia dubia Richard (Crustacea, Cladocera)}

\begin{abstract}
Resumo
A disponibilidade de alimento pode afetar a toxicidade dos metais para os organismos aquáticos. No presente estudo, a influência de alta, média e baixa densidades da alga Pseudokirchneriella subcapitata $\left(10^{6}, 10^{5}\right.$ e $10^{4}$ céls. $\mathrm{mL}^{-1}$, respectivamente) sobre a toxicidade crônica do cromo para o cladócero Ceriodaphnia dubia foi investigada. C. dubia foi exposta a uma faixa de concentração de cromo de 2,71 a 34,04 $\mu \mathrm{g} . \mathrm{L}^{-1}$ e alimentada com diferentes densidades algais. Em outro experimento, a alga foi exposta a concentrações de cromo (94 a $\left.774 \mu \mathrm{g} . \mathrm{L}^{-1}\right)$ e oferecida como alimento ao cladócero em diferentes densidades. A sobrevivência e a reprodução do cladócero foram medidas nesses testes de toxicidade. O valor da CI50 do cromo para $P$. subcapitata e a concentração de metal retido pelas células algais foram determinados. Os resultados da análise bifatorial (metal versus densidades algais) mostraram que a toxicidade do metal ao zooplâncton foi dependente da densidade algal. Efeitos tóxicos significativos na sobrevivência e reprodução de $C$. dubia foram observados a 8,73, 18,22 e 34,04 $\mu \mathrm{g} . \mathrm{L}^{-1} \mathrm{Cr}$ quando o organismo-teste foi alimentado com $10^{6} \mathrm{céls}^{\mathrm{m}} \mathrm{mL}^{-1} \mathrm{de}$ $P$. subcapitata. Apesar de a alga reter pouco cromo, decréscimo na sobrevivência e na reprodução de $C$. dubia ocorreu quando alimentada com alta densidade algal contaminada com $774 \mu \mathrm{g} . \mathrm{L}^{-1} \mathrm{Cr}$. Concluiu-se que alta densidade algal tem uma considerável influência na toxicidade do cromo aos dafinídeos.
\end{abstract}

Palavras-chave: metal, toxicidade crônica, alimento, Pseudokirchneriella subcapitata, zooplâncton.

\section{Introduction}

Heavy metals are introduced into the environment through various human activities, especially those related to industrial and agricultural processes. Chromium salts are used extensively in metal finishing industries such as electroplating, leather tanning, in pigments, in fungicides and in wood preservatives. As a result of the

widespread use in numerous industrial processes, $\mathrm{Cr}$ is a pollutant of air, soil and water (Cervantes et al., 2001).

In order to evaluate the risks due to the discharge of metals into aquatic environments, tests evaluating acute and chronic toxicity on aquatic organisms can be performed. Zooplankton, particularly cladocerans, are 
useful for these tests, due not only to their sensitivity to metal stress, but also to their parthenogenic life cycle ensuring several individuals with little genetic variability and ease to maintain under laboratory conditions (Rand et al., 1995; Pascoe and Edwards, 1989).

In aquatic ecosystems, zooplanktons are exposed both to metal dissolved in the water and to that in the food chain. Munger and Hare (1997) investigated the part played by food as a source of cadmium intoxication for the cladoceran Ceriodaphnia dubia and they concluded that it was an important route for the uptake of the metal by this organism. Weltens et al. (2000) verified that particles (sand, clay, alga) contaminated with cadmium were potentially toxic to Daphnia magna Straus, not only by acting as a source of dissolved metal, but also because the particle-bound fraction of $\mathrm{Cd}$ can become free and available within the body of the filter-feeding organism.

The food, represented by the algae, can act as a channel of metal contamination of cladocerans (Hook and Fisher, 2001) or can counteract metal toxicity, due to their ability to exude organic compounds that complex metal (Lombardi and Vieira, 2000). In addition, the algae contribute to the resistance of the organisms to toxic substances by improving their nutritional state (Chandini, 1989). Since aquatic organisms in their natural environment have food available during toxic exposure, attention should be given to the role of food in toxicity tests (Lanno et al., 1989).

Consideration of the many and diverse interactions that occur between organisms and their environment reveals that other mechanisms may also play a significant role in the eventual fate of toxic agents and their effects within aquatic ecosystems. The reduction in metal toxicity due to a fall in the effective concentration of the chemical, because of its adsorption by food particles, and the toxic effects of ingesting those contaminated food particles, should both be taken into account. In this light, the aim of this study was to evaluate the effects of varying the density of the alga Pseudokirchneriella subcapitata Korshikov, Hindak, (formerly known as Selenastrum capricornutum Printz) on the chronic toxicity of chromium to the cladoceran Ceriodaphnia dubia Richard, when this organism was exposed to this metal dissolved in water and in contaminated food (cells of $P$. subcapitata). These experiments allowed testing the hypothesis that different densities of food may affect chromium toxicity in the case of cladoceran.

\section{Materials and Methods}

\subsection{Culture of test organisms}

Cells of $P$. subcapitata and neonates of $C$. dubia were obtained from the cultures maintained in the Laboratory of Ecotoxicology and Ecophysiology of Aquatic Organisms of the Center of Water Resources and Applied Ecology (CRHEA) of the University of São Paulo (São Paulo State, Brazil).
Cultures of $C$. dubia were maintained in a temperature-controlled chamber at $22 \pm 2{ }^{\circ} \mathrm{C}$ with a 12:12 PM light/dark cycle, using a reconstituted water as the culture medium ( $\mathrm{pH} 7.2$ to 7.6 , conductivity $160 \mu \mathrm{S} / \mathrm{cm}$ and hardness between 42 to $48 \mathrm{mg} . \mathrm{L}^{-1}$ of $\mathrm{CaCO}_{3}$ ) (ABNT, 2005a), the medium being changed every alternate day. The green alga $P$. subcapitata was cultivated in L.C. Oligo medium, which was first autoclaved $\left(121^{\circ} \mathrm{C}\right.$ for 15 minutes) in $2 \mathrm{~L}$ Erlenmeyer flasks containing $1 \mathrm{~L}$ of medium. This was inoculated with cells to a concentration around $1 \times 10^{4}$ cell. $\mathrm{mL}^{-1}$ and the culture was exposed to $100 \mu \mathrm{E} / \mathrm{m}^{2} / \mathrm{s}^{2}$ in $12: 12 \mathrm{PM}$ light/dark cycle, with constant aeration, at $24 \pm 2{ }^{\circ} \mathrm{C}$ (ABNT, 2005b). Algal cells from exponentially-growing $P$. subcapitata cultures were used as food for the zooplankton, $C$. dubia, which was fed every other day with $10^{5}$ cells. $\mathrm{mL}^{-1}$ of the algae and a suspension of yeast and commercial fish food (Vitôrmonio ${ }^{\circledR}$ ), in accordance with the procedures laid out in the Brazilian protocol ABNT (2005a). L.C. Oligo medium and the reconstituted water do not have ethylenediaminetetraacetic acid (EDTA) as component. EDTA is a chelator which may complex metal and interfere in the results of the toxicity tests.

\subsection{Exposure of algae to metal}

Cells of $P$. subcapitata in the exponential growth phase were exposed for 96 hours to a range of nominal concentrations of $0,100,200,400,800$ and $1600 \mu \mathrm{g} . \mathrm{L}^{-1}$ $\mathrm{Cr}$. According to Hook and Fisher (2002), this is the time necessary for cells to have a uniform metal concentration. Test solutions used in this experiment were prepared in volumetric flasks using a volumetric pipettes. Stock solution was $2 \mathrm{mg} . \mathrm{L}^{-1}$ of $\mathrm{K}_{2} \mathrm{Cr}_{2} \mathrm{O}_{7}$ (potassium dichromate, Merck). The dilution water used in the preparation of the test solutions was L.C Oligo medium. Aliquots of algal medium with metal were colleted to measure the total dissolved chromium at the start of the experiment.

After the exposure period, cells were centrifuged at

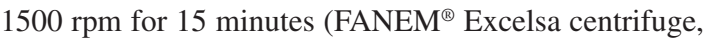
model 206 PM), washed three times with reconstituted water and resuspended in the zooplankton culture water (reconstituted water). Finally, suspensions of the cells were stored in the dark at $4{ }^{\circ} \mathrm{C}$ during the chronic toxicity test with zooplankton (De Schamphelaere and Jassen, 2004).

Samples $(2 \mathrm{~mL})$ from each test flask were taken and fixed with Lugol's iodine solution to determine the cell density, by counting cells in an Improved Neubauer Bright-Line hemocytometer under a Carl Zeiss microscope, Standard model 25. The mean number of cells produced at each concentration, after the exposure period, was expressed as percentage growth reduction with respect to the control. These percentages were used in the calculation of IC50 (effective metal concentration giving $50 \%$ inhibition in algal growth after 96 hours exposure).

Dry weight of algal cells was obtained by filtering a known volume of algal cells on a pre-weighed $0.45 \mu \mathrm{m}$ membrane filter (dried in $480{ }^{\circ} \mathrm{C}$ during 1 hours). Filters 
with algal cells were dried for 24 hours at $60{ }^{\circ} \mathrm{C}$ and weighed to determine the cell mass per volume of culture. The dry weight of the algal cells was obtained by the difference between weight before and after drying (APHA, 1995).

\subsection{Chronic toxicity test}

Test solutions for the chronic toxicity tests with cladocerans were prepared as in the experiments with the alga and the dilution water used in these preparations being reconstituted water. The nominal metal concentrations used in chronic toxicity tests with zooplankton were $2.50,5,10,20$ and $40 \mu \mathrm{g} . \mathrm{L}^{-1}$ of chromium. Samples of test solutions were colleted to measure the total dissolved chromium in the medium at the start of toxicity test.

In the chronic toxicity tests, 10 neonates of $C$. dubia (aged less than 24 hours) were exposed in 10 separate test vessels, to $15 \mathrm{~mL}$ of a certain metal concentration and fed with one of three densities of $P$. subcapitata (low, medium and high: $1 \times 10^{4}$ cells.mL $\mathrm{mL}^{-1}, 1 \times 10^{5}$ cells. $\mathrm{mL}^{-1}$ and $1 \times 10^{6}$ cells. $\mathrm{mL}^{-1}$, respectively). Cladocerans were transferred to a freshly prepared test solution and fed with their respective algal concentration, every other day. A control test, without the added metal, was also prepared. The toxicity tests lasted seven days, the period needed for the production of the third brood, and the number of neonates produced by each female during the experiment and the survival rate of the females at the end were recorded (ABNT, 2005a).

Two controls were used: a laboratory control (LC) that contained the food concentration normally used in the maintenance of the test organism $\left(1 \times 10^{5}\right.$ cells. $\mathrm{mL}^{-1}$ plus the suspension of yeast and fish-food) and another control (C), containing only the algae, at the density being tested. This procedure was a way of testing the physiological condition of the organisms being used in the tests. Chronic toxicity tests were considered valid when a survival of $80 \%$ was observed in adult organisms corresponding to the control laboratory, and when they produced at least 15 neonates per female (ABNT, 2005a).

In another experiment, the cladocerans were fed with algal cells exposed to chromium. The concentrations of metal used to contaminate $P$. subcapitata were close to those that cause $50 \%$ inhibition of the growth of this algal species (Hook and Fisher, 2001). Neonates of C. dubia were exposed to reconstituted water and fed with three different densities of metal-contaminated $P$. subcapitata (low, medium and high: $1 \times 10^{4}$ cells. $\mathrm{mL}^{-1}, 1 \times 10^{5}$ cells. $\mathrm{mL}^{-1}$ and $1 \times 10^{6}$ cells. $\mathrm{mL}^{-1}$, respectively) during seven days. The toxic effects of metal-contaminated algae on reproduction and survival of the $C$. dubia were tested. The feeding and water-changing procedures for this test were similar to those used when this organism was exposed to different metal concentrations.

\subsection{Metal analysis}

To determine total dissolved metal at the beginning of the experiments the samples of test solution from the experiments with the alga and cladoceran were filtered through a $0.45 \mu \mathrm{m}$ membrane filter and then acidified with concentrated nitric acid (J.T. Baker) (APHA, 1995). Total dissolved metal concentrations were used for the analysis of all the results.

At the end of the experiments with P. subcapitata, samples were taken from each different treatment to determine metal in both the suspended (metal accumulated by algal cells) and the total dissolved fractions. To determine the total dissolved metal samples from the experiments were filtered through a $0.45 \mu \mathrm{m}$ membrane filter and acidified with concentrated acid nitric. The filters, with the suspended fraction, were dried and submitted to acid digestion $\left(\mathrm{HNO}_{3}\right.$ and $\mathrm{H}_{2} \mathrm{O}_{2}$ ) (APHA, 1995). The analysis of metals in the algal cells was carried out without EDTA washing, in order not to remove the metals adsorbed on the cell surface. The measured concentration of metal in the algal cells was taken as the total amount of metal accumulated by the cells (i.e. externally and internally bound metal) expressed as $\mu \mathrm{g} \mathrm{Cr} / \mathrm{mg}$ dry weight of algae. Analytical digestion blank was provided using 3 clean filters according to Van Loon (1985). All samples were analysed by graphite-furnace atomic absorption spectrometry (Varian AA 220). The detection limit for Cr, calculated as described in Miller and Miller (1994), was $0.81 \mu \mathrm{g} . \mathrm{L}^{-1}$ for $\mathrm{Cr}$.

\subsection{Statistical analysis}

The IC50 value of chromium for the alga was determined by the Trimmed Spearman-Karber method (Hamilton et al., 1977). The algal cell density results in the experiment with the chlorophyte were submitted to tests for normality (Shapiro-Wilk's test) and homogeneity (Bartlett's test) of the data and then, to Dunnett's test (parametric) to detect significant differences between the controls and each metal treatment.

To test the significance of the effect of algal food densities, total dissolved metal concentrations and different densities of metal-contaminated alga on the survival and reproduction of C. dubia, a two-way ANOVA was employed on the chronic test data, using the BioEstat 2.0 program (Ayres et al., 2000). The numbers of neonates produced by $C$. dubia females were submitted to tests for normality (Shapiro-Wilk's test) and homogeneity (Bartlett's test) and, accordingly, to the Dunnett's (parametric) to detect significant differences between the controls and each metal treatment. Tukey's test (parametric) was used in multiple comparisons to detect significant differences among the reproduction obtained in treatments with different algal densities and metal concentrations. Fisher's exact test was used to distinguish significant differences in the survival of zooplankton, between the control and the various treatments, at the end of the chronic toxicity tests. The above statistical tests were run using the Toxstat version 3.3 computer package (Gulley et al., 1993). 


\section{Results}

\subsection{Exposure of algae to metal}

Table 1 summarizes the effects of metal on the algae and the results of metal analysis. At the start of the experiments, $0,94,185,381,774$ and $1425 \mu \mathrm{g} . \mathrm{L}^{-1}$ total dissolved $\mathrm{Cr}$ was measured in the $0,100,200,400,800$ and $1600 \mu \mathrm{g} . \mathrm{L}^{-1}$ nominal concentrations, respectively. A decrease in the cell density of $P$. subcapitata was observed with increasing concentrations of total dissolved chromium. Concentrations of $774 \mu \mathrm{g} . \mathrm{L}^{-1} \mathrm{Cr}$ reduced the algal cell density to less than half that of the control (without added metal) and dry weight fell similarly. Metal analysis demonstrated that with increasing metal concentration, the accumulation metal concentration also increased, but the green alga was capable of retaining low contents of chromium. At the end of the experiment with the alga, it was observed that chromium was predominant in the total dissolved fraction.

The medium value for the IC50 of Cr to P. subcapitata, on a total of 10 tests, was $534.99 \mu \mathrm{g} . \mathrm{L}^{-1}$ with lower and upper limits of 280.51 and 789.47 , respectively (Figure 1). The coefficient of variation and the standard

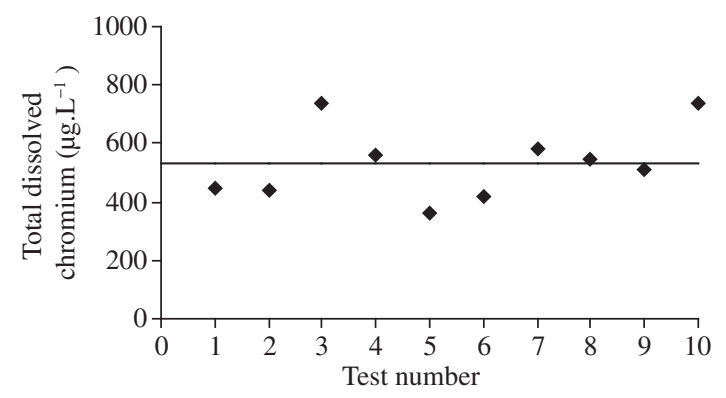

- IC50 Mean value of IC50

Figure 1. Values of IC50 of the chromium for Pseudokirchneriella subcapitata. deviation calculated for these results were $23.78 \%$ and 127.24 , respectively.

\subsection{Chronic toxicity test with zooplankton}

\subsubsection{C. dubia exposed to the chromium concentrations and fed with algae at various densities}

According to bifactorial analysis, reproduction of C. dubia was significantly affected by the food level, the metal concentrations, and also by their interaction (Table 2).

At the start of the chronic toxicity tests, total dissolved chromium concentrations measured in test media were 0 (LC and C), 2.71, 4.50, 8.73, 18.22 and $34.04 \mu \mathrm{g} . \mathrm{L}^{-1}$, this corresponding to 0 (LC and $\mathrm{C}$ ), 2.50, 5, 10, 20 and $40 \mu \mathrm{g} . \mathrm{L}^{-1}$ nominal chromium concentrations, respectively. Figure 2 showed the effects of chromium on the survival and reproduction of $C$. dubia fed with different algal densities. Treatment with $34.04 \mu \mathrm{g} . \mathrm{L}^{-1}$ of chromium at high and low food concentrations affected negatively the survival of C. dubia. Toxic effects on the reproduction of cladoceran during exposure to $34.04 \mu \mathrm{g}$. $\mathrm{L}^{-1} \mathrm{Cr}$, were observed at medium and high food levels. Low reproduction of the test organism were also seen when the females were exposed to 8.73 and $18.22 \mu \mathrm{g} . \mathrm{L}^{-1} \mathrm{Cr}$ and fed with a high density of algal cells. The mean numbers of neonates produced by C. dubia at high algal density and at 8.73 and $34.04 \mu \mathrm{g} . \mathrm{L}^{-1}$ Cr (3.86 neonates/female and 2.00 neonates/female, respectively) were significantly lower than those obtained at medium algal density (9.44 neonates/female and 5.60 neonates/female, in 8.73 and $34.04 \mu \mathrm{g} . \mathrm{L}^{-1} \mathrm{Cr}$, respectively).

\subsubsection{C. dubia fed with metal-contaminated algae at various densities}

The results of bifactorial analysis demonstrated that the survival and reproduction of $C$. dubia were dependent on the interactions between food levels and metal concentrations to which algae cells were exposed (Table 3 ).

When the cells of $P$. subcapitata were exposed to 94.4, 184.90 and $380.8 \mu$ g.L $\mathrm{L}^{-1} \mathrm{Cr}$, chronic toxicity ef-

Table 1. Measurements of dissolved total metal, metal accumulated, cell density and dry weight in experiments with the alga P. subcapitata and chromium. Mean values (SD).

\begin{tabular}{|c|c|c|c|c|c|c|}
\hline $\begin{array}{c}\text { Nominal chromium } \\
\text { concentrations }\left(\mu \mathrm{g} . \mathrm{L}^{-1}\right)\end{array}$ & C & 100 & 200 & 400 & 800 & 1600 \\
\hline $\begin{array}{l}\text { Total dissolved chromium at start } \\
\text { of exposure }\left(\mu \mathrm{g} . \mathrm{L}^{-1}\right)\end{array}$ & 0 & $\begin{array}{l}94.40 \\
(5.60)\end{array}$ & $\begin{array}{l}184.90 \\
(7.50)\end{array}$ & $\begin{array}{l}380.80 \\
(24.80)\end{array}$ & $\begin{array}{c}774 \\
(3.25)\end{array}$ & $\begin{array}{l}1425 \\
(11)\end{array}$ \\
\hline $\begin{array}{l}\text { Total dissolved metal after } 96 \\
\text { hours of exposure }\left(\mu \mathrm{g} \cdot \mathrm{L}^{-1}\right)\end{array}$ & 0 & $\begin{array}{l}82.84 \\
(8.48)\end{array}$ & $\begin{array}{l}176.79 \\
(26.11)\end{array}$ & $\begin{array}{l}319.20 \\
(25.05)\end{array}$ & $\begin{array}{l}707.80 \\
(40.49)\end{array}$ & $\begin{array}{c}1326 \\
(18.88)\end{array}$ \\
\hline $\begin{array}{l}\text { Chromium accumulated by algal } \\
\text { cells }(\mu \mathrm{g} / \mathrm{mg})\end{array}$ & 0 & $\begin{array}{l}0.03 \\
(0.02)\end{array}$ & $\begin{array}{c}0.04 \\
(0.01)\end{array}$ & $\begin{array}{c}0.11 \\
(0.02)\end{array}$ & $\begin{array}{c}0.27 \\
(0.13)\end{array}$ & $\begin{array}{c}2.13 \\
(0.94)\end{array}$ \\
\hline $\begin{array}{l}\text { Mean cell density after } 96 \text { hours } \\
\text { of exposure }\left(10^{6} \text { cells. } \mathrm{mL}^{-1}\right)\end{array}$ & $\begin{array}{c}5.83 \\
(1.47)\end{array}$ & $\begin{array}{c}5.07 \\
(1.72)\end{array}$ & $\begin{array}{c}4.83 \\
(1.45)\end{array}$ & $\begin{array}{l}3.97 * \\
(1.53)\end{array}$ & $\begin{array}{l}2.13 * \\
(1.07)\end{array}$ & $\begin{array}{l}0.10^{*} \\
(0.09)\end{array}$ \\
\hline $\begin{array}{l}\text { Dry weight }\left(\mathrm{mg} \cdot \mathrm{L}^{-1}\right) \text { after } 96 \\
\text { hours of exposure }\end{array}$ & $\begin{array}{l}110.73 \\
(18.53)\end{array}$ & $\begin{array}{l}121.5 \\
(29.77)\end{array}$ & $\begin{array}{l}111.87 \\
(39.14)\end{array}$ & $\begin{array}{l}111.23 \\
(2.62)\end{array}$ & $\begin{array}{c}49.57 * \\
(19.8)\end{array}$ & $\begin{array}{l}9.77 * \\
(2.33)\end{array}$ \\
\hline
\end{tabular}

$\mathrm{C}$ (control) and *indicates statistically different from control $(\mathrm{C})$ (Dunnett's test, $\mathrm{P}<0.05$ ). 
Table 2. Results of two-way analyses of variance applied to data of survival and reproduction of $C$. dubia when exposed to several dissolved chromium concentrations with different algal densities (d.f: degree of freedom; P: probability).

\begin{tabular}{ccrrr}
\hline Parameter & Source of variation & F & d.f. & P \\
\hline Survival & Food & 2.00 & 2,162 & $<$ \\
& Metal & 14.76 & 5,162 & $<0.001$ \\
& Food x Metal & 2.10 & 10,162 & 0.02 \\
Reproduction & Food & 193.27 & 2,126 & $<0.001$ \\
& Metal & 14.76 & 5,126 & $<0.001$ \\
& Food x Metal & 5.46 & 10,126 & $<0.001$ \\
\hline
\end{tabular}

$\mathrm{NS}=$ not significant $(\mathrm{P}>0.05)$.

(a)
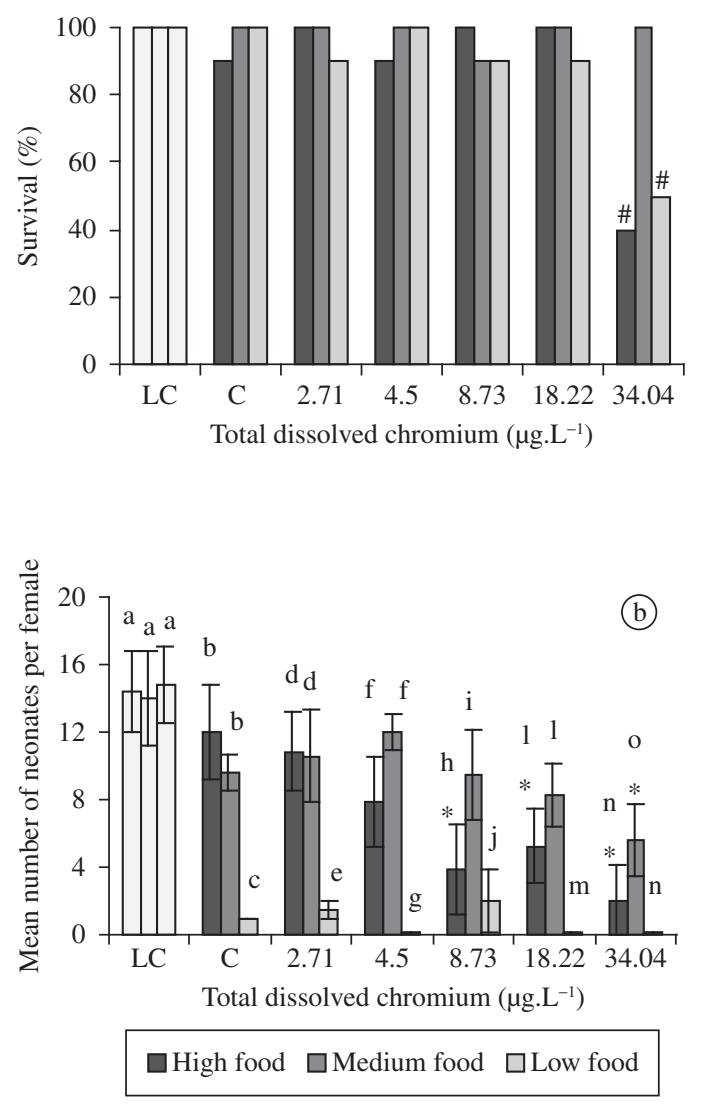

Figure 2. a) Percent of survival and b) mean number of neonates of $C$. dubia, in chronic toxicity test for chromium, when it was fed with various algal densities of $P$. subcapitata. LC (laboratory control) and C (control). Survival: \#indicates statistically different from the control (C) (Fisher's exact test, $\mathrm{P}<0.05)$. Reproduction: *indicates statistically different from the control (C) (Dunnett's test, $\mathrm{P}<0.05$ ) and means with the different letters are significantly different (Test of Tukey, $\mathrm{P}<0.05)$. Error bars denote standard deviation.

fects were not observed in $C$. dubia fed on these cells. Survival and reproduction of adult zooplankton was only affected when they were fed with high algal density contaminated with $774 \mu \mathrm{g} . \mathrm{L}^{-1}$ of metal (Figure 3).
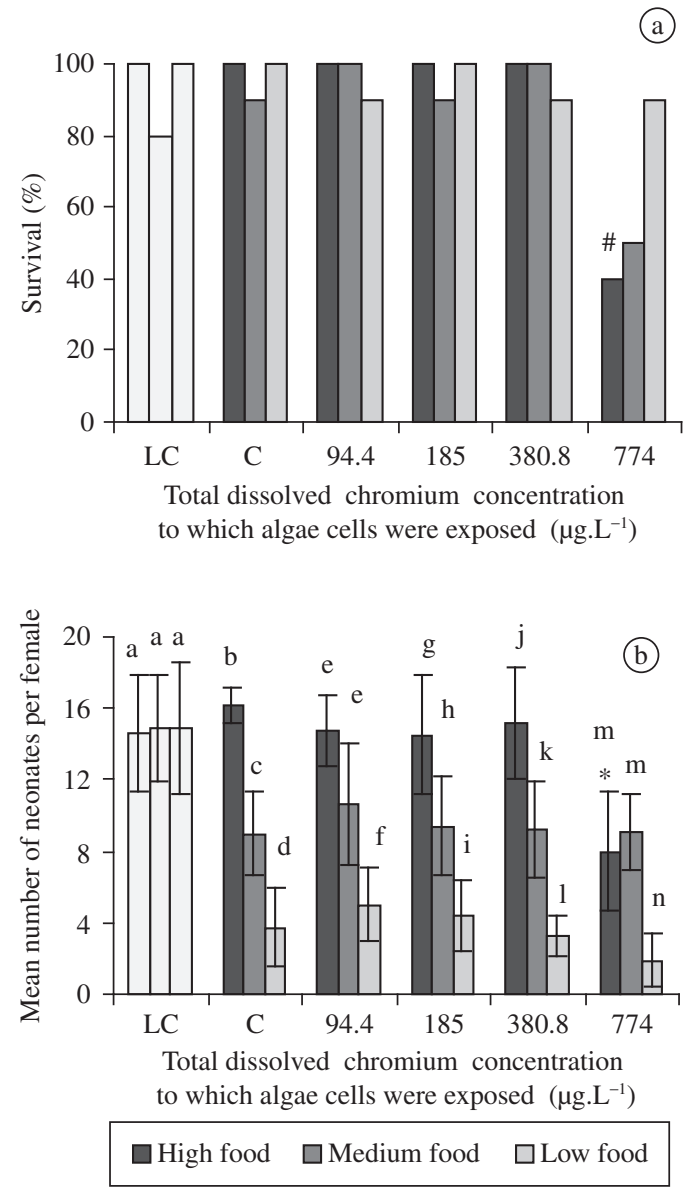

Figure 3. a) Percent of survival and b) mean number of neonates of $C$. dubia when fed with various algal densities of $P$. subcapitata previously exposed to chromium. LC (laboratory control) and C (control). Survival: \#indicates statistically different from the control (C) (Fisher's exact test, $\mathrm{P}<0.05)$. Reproduction: *Indicates statistically different from the control $(\mathrm{C})$ (Dunnett's test, $\mathrm{P}<0.05$ ) and means with the different letters are significantly different (Test of Tukey, $\mathrm{P}<0.05)$. Error bars denote standard deviation.

Considering both tests of chronic toxicity, the reproduction and survival of $C$. dubia were lower in metal contaminated water with different algal densities than those observed when $C$. dubia was exposed to metal 
Table 3. Results of two-way analyses of variance applied to data of survival and reproduction of $C$. dubia when this organism was fed with metal-contaminated algae at various densities (d.f: degree of freedom; P: probability).

\begin{tabular}{clrrr}
\hline Parameter & Source of variation & F & d.f. & P \\
\hline Survival & Food & 0.62 & 2,135 & $<$ S \\
& Metal & 6.48 & 4,135 & 0.001 \\
& Food x Metal & 3.37 & 8,135 & $<02$ \\
\multirow{2}{*}{ Reproduction } & Food & 127.47 & 2,105 & $<0.001$ \\
& Metal & 7.38 & 4,105 & 0.001 \\
& Food x Metal & 3.00 & 8,105 & 0.004 \\
\hline
\end{tabular}

$\mathrm{NS}=$ not significant $(\mathrm{P}>0.05)$.

contamination through food. At low food concentrations $\left(10^{4}\right.$ cells. $\left.\mathrm{mL}^{-1}\right)$, in both treatments (water and food contaminated), there was a decrease in the number of neonates produced per female in the control at all the chromium metal concentrations. Thus, low food density itself caused a decrease in the rate of reproduction of the test organism.

\section{Discussion}

A new approach in ecotoxicological studies has focused on the influence of food on the effects of metals in zooplankton. Our study showed that the mean numbers of neonates produced by $C$. dubia during exposure to 8.73 and $34.04 \mu \mathrm{g} . \mathrm{L}^{-1} \mathrm{Cr}$, in the presence of high algal density, were significantly smaller than those obtained at medium algal density. The analysis of the combined effects of food level and metal concentration showed that metal toxicity was dependent on food level, this result agrees with the independent analyses done with each food level.

In general, cladocerans cannot tolerate an algal level higher than $4 \times 10^{6}$ cells. $\mathrm{mL}^{-1}$, because such densities can depress their rate of feeding (Nandini and Sarma, 2000). In this study, the rate of feeding of $C$. dubia was not monitored, however the highest food density used $\left(1 \times 10^{6}\right.$ cells. $\left.\mathrm{mL}^{-1}\right)$ was less than $4 \times 10^{6}$ cells. $\mathrm{mL}^{-1}$. Under control conditions, the reproduction of $C$. dubia was observed to rise with increasing algal density supplied, and it was significantly reduced by a density of $1 \times 10^{4}$ cells. $\mathrm{mL}^{-1}$ of $P$. subcapitata. Algal concentrations of $10^{6}$ cells. $\mathrm{mL}^{-1}$ probably occur in eutrophic environments (Kobayashi, 1992), so that studies using this algal density would help in the understanding of metal dynamics in polluted aquatic systems.

Metal toxicity in zooplanktons may vary with the density of algae offered to the organisms. For example, at low metal concentrations, an increased algal level can enhance the resistance of the species (Sarma et al., 2000). This effect was not observed in the present study, in which toxic effects to $C$. dubia were demonstrated when it was exposed to low metal concentrations $\left(8.73 \mu \mathrm{g} . \mathrm{L}^{-1} \mathrm{Cr}\right)$ while being fed with a high density of algae.

Algae have been reported to reduce contaminant toxicity in ecotoxicological studies with cladocerans. Antunes et al. (2004) observed a decrease in the chronic toxic effect of the pesticide lindane to D. magna when this cladoceran was exposed to a high density of P. subcapitata $\left(6 \times 10^{5}\right.$ cells. $\left.\mathrm{mL}^{-1}\right)$. The presence of a high food density $\left(10^{6}\right.$ cells. $\mathrm{mL}^{-1}$ of Chlorella vulgaris Beijerink) reduced the effects of cadmium on the reproduction and survival of cladocerans Moina macrocopa Goulden and Macrothrix triserialis Brady, compared to the results obtained with a lower algal density (Garcia et al., 2004). Hauri and Horne (2004) showed that a large amount of algal food reduced the availability of labile copper to $C$. dubia during chronic toxicity tests, due to the complexing of the metal by food particles. The authors reached a general conclusion that a high food level could supply additional energy for growth and reproduction and, at the same time, for specific mechanisms of detoxification and of resistance to toxic agents.

The results of the present study are consistent with those obtained by Gorbi et al. (2002), who observed that the fecundity of D. magna was affected negatively by concentrations of $14 \mu \mathrm{g} . \mathrm{L}^{-1}$ of $\mathrm{Cr}$, only at high concentrations of the alga Scenedesmus acutus Meyen. This toxic effect was attributed to a possible absorption by the daphnids of the metal complexes formed between the chromium and exudates liberated by the green algae as a response to exposure to the metal. In our study, when the females of $C$. dubia were exposed to chromium at a high algal density, they could have absorbed more metal-exudates complexes through filtration mechanisms, and within the body of organisms, metal may have become toxic.

In the present study, $P$. subcapitata removed small amounts of chromium from the solution. Travieso et al. (1999) also observed low removal of chromium by the green algae $S$. acutus and $C$. vulgaris, compared to other metals. Corradi et al. (1998) found that S. acutus produced algal exudates with greater amounts of carbohydrates when exposed to chromium. Algal exudates are capable of metal complexation, thus reducing its toxicity.

Although the cells of $P$. subcapitata only retain a low chromium content, a decrease in the reproduction and survival of the zooplankton occurred when the chlorophyte cells were exposed to $774 \mu \mathrm{g} . \mathrm{L}^{-1} \mathrm{Cr}$ and supplied as food. According to Gorbi and Corradi (1993), that metal transfer along the algae-daphnids food chain is not efficient and suggested that chromium is accumulated by algae in chemical forms not available for 
the consumer organisms. On the other hand, algae contaminated with $774 \mu \mathrm{g} . \mathrm{L}^{-1} \mathrm{Cr}$ and offered to $C$. dubia at high density might have released chromium back into the medium during the chronic toxicity test. Thus, toxic effects observed in the zooplankton could be attributed to the metal dissolved in the medium. Unfortunately, dissolved chromium concentration was not monitored during this experiment.

Food quality is at least as important as quantity, for the fecundity, population growth and survival of cladocerans (Kilham et al., 1997). The observed reduction of reproduction of $C$. dubia might result from a diet quality effect; in other words, metal could have affected the nutritional value of the algal cells to which they were exposed. High chromium concentrations cause a degradation of algal cell proteins, consequently lowering their nutritional value to their consumers (Gorbi et al., 2004).

When $C$. dubia was exposed to high density of food contaminated by chromium, the toxic effect were less pronounced than those obtained when the test organism was exposed to chromium dissolved in water with high algal densities. The present results imply that water was an important route of exposure to chromium for the cladoceran and this agrees with the findings of Barata et al. (2002), who showed that water was a major pathway of metal uptake for D. magna, although a substantial amount of the toxic element was obtained by the test organism from the contaminated food.

Algal cells should be considered as a factor that has an appreciable influence on metal toxicity to cladocerans. Ecotoxicological studies should consider the influence of varying algal densities on the expression of metal toxicity on daphnids. In this context, to provide more information about the sources of metal contamination to cladocerans, future research should analyze the final metal concentration in water, food and zooplanktons in toxicity tests with metal at different algal concentrations.

Acknowledgements - The authors would like to thank the National Research Council (CNPq: Process no. 140156/2002-0) and the State of São Paulo Research Aid Foundation (FAPESP: Process no. 10417/2002) for their financial support and the PostGraduation Program in Environmental Engineering Sciences of the Engineering School of São Carlos of the University of São Paulo.

\section{References}

AMERICAN PUBLIC HEALTH ASSOCIATION, AMERICAN WATER WORK ASSOCIATION and WATER CONTROL FEDERATION, 1995. Standard methods for the examination of water and wastewater. $19^{\text {th }}$ ed. New York. p. 3-1-3-19.

ANTUNES, SC., CASTRO, BB. and GONÇALVES, F., 2004. Effect of food level on the acute and chronic responses of daphnids to lindane. Environ. Pollution., vol. 127, p. 367-375.

ASSOCIAÇÃO BRASILEIRA DE NORMAS TÉCNICAS - ABNT, 2005a. NBR 13373. Ecotoxicologia aquática Toxicidade crônica - Método de ensaio com Ceriodaphnia ssp (Cladocera, Crustacea). Rio de Janeiro. 15 p.
ASSOCIAÇÃO BRASILEIRA DE NORMAS TÉCNICAS ABNT, 2005b. NBR 12468. Ecotoxicologia aquática-Toxicidade crônica - Método de ensaio com algas (Chlorophyceae). Rio de Janeiro. 24 p.

AYRES, M., AYRES-Jr, M., AYRES, DL. and SANTOS, AS., 2000. BioEstat 2.0: aplicações estatística na área das Ciências Biológicas e Médicas. Mamirauá: Sociedade Civil Lithera Maciel. Editora Grágica Ltda. 324 p.

BARATA, C., MARKICH, SJ., BAIRD, DJ. and SOARES, AMVM., 2002. The relative importance of water and food as cadmium sources to Daphnia magna Straus. Aquatic Toxicol., vol. 61, p. 143-154.

CERVANTES, C., CAMPOS-GARCIA, J., DEVARS, S., GUTIÉRREZ-CORONA, F., LOZA-TAVERA, H., TORRESGUZMÁN, JC. and MORENO-SÁNCHEZ, R., 2001. Interactions of chromium with microorganisms and plants. FEMS Microbiology Reviews, vol. 25, p. 335-347.

CHANDINI, T., 1989. Survival, growth and reproduction of Daphnia carinata (Crustacea:Cladocera) exposed to chronic cadmium stress at different food (Chlorella) levels. Environ. Pollution, vol. 60, p. 29-45.

CORRADI, MG., GORBI, G., ABD-EL-MONEM, H, TORELLI, A. and BASSI, M., 1998. Exudates from the wild type and a Cr-tolerant strain of Scenedesmus acutus influence differently $\mathrm{Cr}$ (VI) toxicity to algae. Chemosphere, vol. 37, no. $14-15$, p. 3019-3025.

DE SCHAMPHELAERE, KAC. and JANSSEN, CR., 2004. Effects of chronic dietary copper exposure on growth and reproduction of Daphnia magna. Environ. Toxicol. Chem., vol. 23 , no. 8 , p. 2038-2047.

GARCIA, GG., NANDINI, S. and SARMA, SSS., 2004. Effects of cadmium on the populations of Moina macrocopa and Macrothrix triserialis (Cladocera). Bull. Environ. Contamin. Toxicol, vol. 72, p. 717-724.

GORBI, G. and CORRADI, MG., 1993. Chromium toxicity on two linked trophic levels. I. Effects of Contaminated Algae on Daphnia magna. Ecotoxicol. Environ. Saf., vol. 25, p. 64-71.

GORBI, G., CORRADI, MG., INVIDIA, M., RIVARA, L. and BASSI, M., 2002. Is Cr (VI) toxicity to Daphnia magna modified by food availability or algal exudates? The hypothesis of a specific chromium/algae/exudate interaction. Water. Res., vol. 36, p. 1917-1926.

GORBI, G., INVIDIA, M., ZANINI, C., TORELLI, MG. and CORRADI, MG., 2004. Bioavailability, bioaccumulation and tolerance of chromium: consequences in the food chain of the freshwater ecosystems. Annali di Chimica, vol. 94, no. 7/8, p. 505-513.

GULLEY, DD., BOELTER, AM. and BERGMAN., HL., 1993. Toxstat Version 3.3. Computer Program. Fish Physiology and Toxicology Laboratory Department of Zoology and Physiology University of Wyoming Laramie.

HAMILTON, M., RUSSO, RC. and THURSTON, RV., 1977. Trimmed Spearman-Karber method for estimating median lethal concentrations in toxicity bioassays. Environ. Sci. Tech., vol. 11, no. 7, p. 714-719.

HAURI, JF. and HORNE, AJ., 2004. Reduction in labile copper in the 7-day Ceriodaphnia dubia toxicity test due to the interaction with zooplankton food. Chemosphere, vol. 56, p. 717-723. 
HOOK, SE. and FISHER, NS., 2001. Sublethal effects of silver in zooplankton: importance of exposure pathways and implications for toxicity testing. Environ. Toxicol. Chem, vol. 20 , no. 3 , p. $568-574$.

HOOK, SE., FISHER, NS., 2002. Relating the reproductive toxicity of five ingested metals in calanoid copepods with sulfur affinity. Mar. Environ. Research, vol. 53, p. 161-174.

KILHAM, SS., KREEGER, DA., GOULDEN, CE. and LYNN, SG. 1997. Effects of algal quality on fecundity and population growth rates of Daphnia. Freshwater Biology, vol. 38, p. 639-647.

KOBAYASHI, T., 1992. A study of physicochemical conditions phytoplankton and microcrustacean zooplankton in Wallerawang Reservoir, New South Wales. Proc. Linn. Soc. N. S., vol. 113, p. 27-41.

LANNO, RP., HICKIE, BE. and DIXON, DG., 1989. Feeding and nutricional considerations in aquatic toxicology. Hydrobiologia, vol. 188/189, p. 525-531.

LOMBARDI, AT. and VIEIRA, AAH., 2000. Copper complexation by Cyanophyta and Chlorophyta exudates. Phycologia., vol. 39, no. 2, p. 118-125.

MILLER, JC. and MILLER, JN., 1993. Statistics for analytic chemistry. 3ed. Prentice Hall. 200 p.

MUNGER, C. and HARE, L., 1997. Relative importance of water and food as cadmium source to an aquatic insect (Chaoborus punctipennis): implications for predicting $\mathrm{Cd}$ bioaccumulation in nature. Environ. Sci. Technol, vol. 31, p. 891-895.
NANDINI, S. and SARMA, SSS., 2000. Lifetable demography of four cladoceran species in relation to algal food (Chlorella vulgaris) density. Hydrobiologia, vol. 435, p. 117-126.

PASCOE, D. and EDWARDS, RW., 1989. Single species toxicity tests. In BOUDOU, A. and RIBEYRE, F. (ed). Aquatic ecotoxicology: fundamental concepts and metodologies. Florida: Boca Raton. p. 94-119.

RAND, GM., WELLS, PG. and MCCARTY, LS., 1995. Introduction to Aquatic Toxicology. In RAND, GM. (ed), Fundamentals of aquatic toxicology: effects, environmental fate, and risk assessment. Washington: Taylor \& Francis. p. 3-66.

SARMA, SSS., RAMÍREZ, TP. and NANDINI, S., 2000. Comparison of the sensitivy of Brachionus calyciflorus and Brachionus patalus (Rotifera) to selected heavy metals under low and high food (Chlorella vulgaris) level. Bull. Environ. Contam. Toxicol., vol. 64, p. 735-739.

TRAVIESO, L., CANIZARES, RO., BORJA, R., BENÍTEZ, F., DOMÍNGUEZ, AR., DUPEYRÓN, R., VALIENTE, V., 1999. Heavy metal removal by microalgae. Bull. Environ. Contam. Toxicol, vol. 62, p. 144-151.

VAN-LOON, JC., 1985. Select methods of trace metal analysis. United States: Ed. John Wiley Interscience.

WELTENS, R., GOOSSENS, R. and VAN PUYMBROECK, S., 2000. Ecotoxicity of contaminated suspended solids for filter feeders (Daphnia magna). Arch. Environ. Contam. Toxicol., vol. 39, p. 315-323. 